\title{
VSO HOSPICE CARE IN RUSSIA
}

\section{Maureen Cummings, retired Macmillan nurse}

What would make one leave England, having just retired as a Macmillan nurse, and come to Russia to work as a VSO volunteer? Maybe the impossibility of the job, which asked for someone of my background to work with a university professor who had set up "Hospice Volunteers". This she had done in her own time in a large industrial city in the Urals, a city with no hospice in a country which has no recent tradition of volunteering - unless associated with compulsory or political activity. A volunteer was sought to work with seriously ill patients in their own homes. How could one resist the challenge?

\section{PRE-PERESTROIKA}

The development of voluntary organisations is part of the reestablishment of democracy in Russia. Under the Soviet system, public activities were led by government or party organisations including social or "charitable work". The development of independent non-governmental activities to generate ideas and address different needs was actively discouraged. Until the mid-1960s the system of healthcare was remarkably successful, raising life expectancy almost to the same levels as western Europe, having started from lower levels. This success was achieved through public health, sanitation, hygiene and mass vaccination. Unfortunately, as the health service ministry became more dominant and the public health ministry less so, disease prevention disappeared from the medical and nursing schools' curriculum, the emphasis being placed on technical medicine and the cure of disease - the medical model.

\begin{tabular}{|l|c|c|c|c|}
\hline & \multicolumn{2}{|c|}{ RUSSIA } & \multicolumn{2}{c|}{ ENGLAND } \\
\hline & M & F & M & F \\
\hline 1896 & 31 & 33 & & \\
\hline 1901 & & & 48 & 58 \\
\hline 1926 & 42 & 47 & & \\
\hline 1931 & & & 58 & 63 \\
\hline 1966 & 66 & 74 & 68 & 75 \\
\hline
\end{tabular}

Life expectancy in England and Russia

\begin{tabular}{|c|c|c|c|c|}
\hline & \multicolumn{2}{|c|}{ RUSSIA } & \multicolumn{2}{c|}{ ENGLAND } \\
\hline & M & F & M & F \\
\hline 1985 & 63.8 & 74.0 & 71.3 & 77.3 \\
\hline 1992 & 62.0 & 73.7 & 73.7 & 79.1 \\
\hline 1993 & 58.9 & 71.9 & 74.0 & 79.3 \\
\hline 1994 & 57.6 & 71.2 & 74.1 & 79.4 \\
\hline 1995 & 58.2 & 71.7 & 74.4 & 79.6 \\
\hline 1996 & 59.7 & 72.5 & 74.6 & 79.7 \\
\hline 1997 & 60.7 & 72.9 & & \\
\hline
\end{tabular}

Average life expectation at birth

The closed Soviet system was also isolated from the influences that have been shaping health services in the UK during the past 30 years, such as:
- patients' individual rights and the doctor/patient relationship

- multidisciplinary working and hospice care

- evidence-based medicine

- cost effectiveness

- modern management

- freedom of information

The overall effect can be seen in UNDP Report (Poverty in Transition) 1998. Mortality rates began to rise and life expectancy slowed, then stopped. Most of the excess mortality was due to accidents and cardiovascular disease attributed to smoking, alcohol, diet and lack of exercise. There is very little health promotion, eg seat belts are not worn, and in 1999 there were 30,000 deaths from accidents and alcoholic poisoning, $14 \%$ of the overall mortality rate. A consultant's secretary recently remarked to me that the Russian male is becoming extinct like the mammoth.

\begin{tabular}{|l|c|c|}
\hline & RUSSIA 1997 & ENGLAND 1998 \\
\hline all causes & 1380 & 1046 \\
\hline infectious diseases & 21 & \\
\hline neoplasms & 202 & 258 \\
\hline diabetes & & 11 \\
\hline cardiovascular diseases & 751 & 426 \\
\hline ischaemic heart disease & & 227 \\
\hline stroke & & 108 \\
\hline respiratory disease & 64 & 153 \\
\hline pneumonia & & 103 \\
\hline chronic digestive diseases & 38 & 8 \\
\hline cirrhosis & 186 & 20 \\
\hline all accidents & 22 & 6 \\
\hline transport & 38 & 10 \\
\hline suicide & \\
\hline \multicolumn{2}{|c|}{ Causes of death per 100,000 population } \\
\hline
\end{tabular}

\section{POST-PERESTROIKA}

Since the collapse of the Soviet Union in 1991, Russia has been undergoing a process of transition to democracy and a market economy. There are now many social problems and vulnerable groups: women and children, those with disabilities and older people, all of whom are worse off than under the Soviet Union. Under that system the health service was free and everyone had access to care.

Russian people are concerned about long waiting times in clinics, poor physical conditions of many health facilities, poor trained doctors and a lack of good modern equipment. Medicines are often unobtainable and since the further collapse of 1998 are less likely to be imported.

They see medical staff as overwhelmed and undervalued (nurses' salary is equivalent to $£ 20$ per month) and know that many have two or three jobs. 
It is interesting to compare the staffing and beds situations in Russia with those of the UK.

\begin{tabular}{|l|c|c|}
\hline & RUSSIA & BRITAIN \\
\hline hospital beds & 119.0 & 39.2 \\
\hline total doctors & 46.9 & 16.9 \\
\hline $\begin{array}{l}\text { total nurses and } \\
\text { doctors assistants }\end{array}$ & 111.0 & 70 \\
\hline
\end{tabular}

Hospital beds and medical personnel per 10,000 population in 1998

They are unhappy too about the paternalistic attitudes of the medical staff. Information is often given reluctantly and is sparse. It is common practice not to tell patients that they have cancer, although relatives are told. When talking with nurses, the justification for this was that their patients would give up hope and lose the will to live. A further reason given was that since many patients present with advanced disease, and palliative care services are limited, little would be gained by telling the truth.

\section{THE LOCAL SITUATION}

My boss calls herself a Russian scientist and believes in energy fields, crystals and live and dead water. She is interesting but can produce no research evidence. There were very few volunteers when I arrived, but following a media launch the training has begun. Two oncology hospitals are setting aside beds for palliative care and hospice volunteers are to be involved. Home care teams are planned which should encourage multidisciplinary team working, and also raise the status of the nurses. I am running workshops for the oncology nurses who are interested in how palliative care is practised in the UK.
With the help of an excellent interpreter I am privileged to visit a young man of 22 with lymphoma. He has a complicated history and is now paraplegic. Although I assure him and his lovely caring mother that people are not always cured of their disease in the UK, I am not sure that they believe me. We offer them both support and aromatherapy which they seem to appreciate.

The setting-up of a hospice, although planned, is probably too ambitious until the economy improve and stabilises. The Moscow hospice, which is quite luxurious by Russian standards, relies heavily on the comparative prosperity of its capital city and some prosperous inhabitants. They have problems with day care due to the climate and transport difficulties and the accessibility of ill patients in high-rise flats, which most of us inhabit. There are also problems with security, due partly to having morphine on the premises and it being situated in the centre of Moscow.

\section{CONCLUSION}

The Russian winter is now well established - clear blue skies on many days, crisp and cold with glistening snow. The people are generally warm and friendly and keen to know about life in England. I have spoken on a late night radio phone-in for sad Russians who cannot sleep. I am sure that the next nine months will be challenging but, hopefully, also rewarding. Russians are great party people and amazingly stoical - their language, however is impossible!

\section{Acknowledgment}

I would like to thank Dr Richard Waldram, VSO volunteer in Russia 1999/2000, for allowing me to use some of the data used in his report Health and Health Services in Russia. 